\title{
Kernos
}

Revue internationale et pluridisciplinaire de religion grecque antique

15 | 2002

Varia

\section{Physiology and Mysticism at Pherai. The Funerary Epigram for Lykophron}

\author{
Aphrodite A. Avagianou
}

\section{(apenEdition \\ Journals}

Electronic version

URL: http://journals.openedition.org/kernos/1368

DOI: 10.4000/kernos. 1368

ISSN: 2034-7871

\section{Publisher}

Centre international d'étude de la religion grecque antique

\section{Printed version}

Date of publication: 1 January 2002

ISSN: 0776-3824

\section{Electronic reference}

Aphrodite A. Avagianou, «Physiology and Mysticism at Pherai. The Funerary Epigram for Lykophron», Kernos [Online], 15 | 2002, Online since 21 April 2011, connection on 20 April 2019. URL : http:// journals.openedition.org/kernos/1368; DOI : 10.4000/kernos.1368 


\section{Physiology and Mysticism at Pherai. The Funerary Epigram for Lykophron*}

To the starry beaven, where my soul will live.

For historians of religion, a funerary epigram from Pherai dated to the early Hellenistic period ${ }^{1}$ has special interest. The text is as follows:

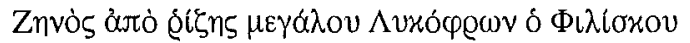

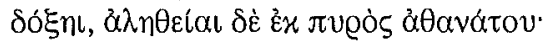

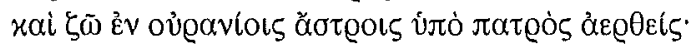

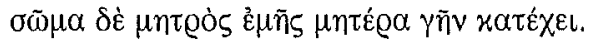

I, Lykophron, the son of Philiskos, seem sprung from the root of great Zeus, but in truth am from the immortal fire; and I live among the heavenly stars uplifted by my father; but the body born of my mother occupies mother-earth.

The main idea of the epigram, that the soul of the dead goes to the astral heaven while the body returns to the earth, that is, the mother, is easy to grasp and it could be argued that this notion is a standard expression in funerary epigrams. The purpose of my paper, however, is to show that this idea expresses a specific conception of the nature of the cosmos and of the human soul with its own specific vocabulary.

A full analysis of the text requires examination of the following aspects: 1) the Presocratic physiology-cosmogony underlying it and its function in the context of the epigram; 2) the religious tendencies which emerge and their place in contemporary mystic trends; 3 ) the language and the techniques used to reinforce the twofold message of the epigram.

* I am deeply thankful to Prof. Dr. W. Burkert for his constant, intellectual support and invaluable suggestions on this paper. I am indebted to Prof. Dr. D. Zeller for his precious comments and references, after delivering the paper in the 8th International Conference of CIERGA (Rhodes, 25-29 May 2001). I would also like to record my appreciation to Prof. Dr. Y.Z. Tzifopoulos for his scrutinizing but perceptive comments as well as for some additional bibliography.

1 Ed. pr. D.P. Theocharis, AD 22 (1967), Chron., p. 297 and ill. 196. BullEpigr (1970), 337 and (1974), 309. Also, R. Merkelbach, "Epigram auf Lykophron von Pherai", ZPE 11 (1973), p. 156. Republished by W. PEEk, Griechische Vers-Inschriften aus Thessalien, Sitz. Ber. Heidelberger Akad. Wiss., Ph.-Hist. Kl., 1974, Abh. 3, no. 25, p. 27-28 (ill.); SEG 28 (1978), 528; B. Helly, RPb (1978), p. 130. 


\section{A. $\Delta o ́ \xi \alpha$ : 'A $A \hat{n} \theta \varepsilon \iota \alpha=$ Seeming : Truth}

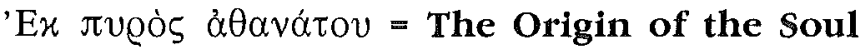

Orphic poetry adapted language to fit Orphic mysticism, especially for the purpose of revealing doctrine. ${ }^{2}$ The linguistic style and mode of presentation derived apparently not only from writings on physiology but also from the language of the mysteries and its content was analogous to contemporary mystic doctrine. ${ }^{3}$ In reconstructing the cosmogony, we have to take into account the role of language, as well as the structure of the epigram, which is based on the principles of dualism and opposition.

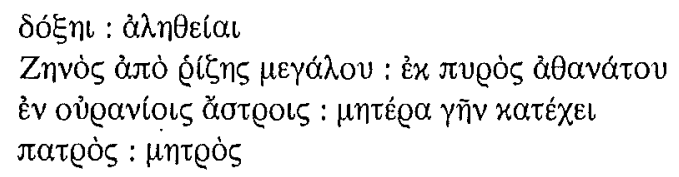

The text contrasts $\delta o ́ \xi \alpha: \dot{\alpha} \lambda \dot{n} \theta \varepsilon\llcorner\alpha$ (doxa : aletbeia), a contrast paralleled in the following texts:

a) The first (the Prooemium) and second part of Parmenides' poem Ilei

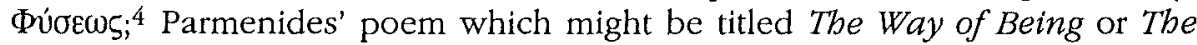
Way of Truth is divided into three parts: A Prooemium (Fragment 1), that sets the famous contrast between Truth and Opinion (Being and Seeming), a section referred to as The Way of Truth or Aletheia and a section The Way of Seeming; b) The same contrast is expressed by Xenophanes in the

2 See D. Gambarara, Alle fonti della filosofia del languaggio. 'Lingua' e 'nomi' nella cultura greca arcaica, Rome, 1984, p. 168-180. Also, A. BerNABÉ, "Una forma ebrionaria de reflexión sobre el lenguaje: la etimología de nombres divinos en los órficos", Revista española de lingüística 22 (1992), p. 26-54.

3 W. Burkert has pointed out the important role the commentator of Papyrus Derveni assigned to language by assimilating cosmogony to onomatogony: W. BuRKERT, "La Genèse des choses et des mots. Le papyrus de Derveni entre Anaxagore et Cratyle", EPb 25 (1970), p. 443-455.

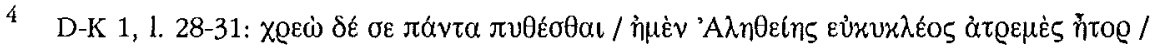

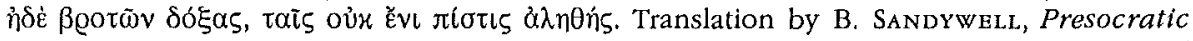
Reflexivity: The Constmuction of Pbilosopbical Discourse c. 600-450 B.C., vol. 3, London / New York, 1996, p. 305: "You will learn everything: both the immoveable heart of wellrounded Truth, and the opinions of mortals, in which there is no truly convincing force"

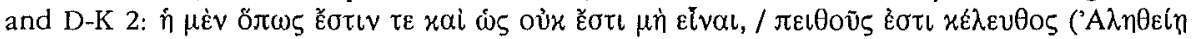
$\gamma \dot{\alpha} \varrho \varrho$ o $\pi \eta \delta \varepsilon \tilde{i}$ ). Translation by B. SANDYwELL, o.c., p. 305: "The first, that says that [It] is, and that it is not possible for [It] not to be - this is the path of true persuasion, for it follows Truth". (G.S. Kirk, J.E. Raven, M. Schofield, The Presocratic Philosophers, Cambridge Univ. Press, $1983^{2}$, p. 288 and 291).

5 See SANDYWELl, o.c. (n. 4), p. 300 sq. 
Fragment on the limitations of human knowledge, 6 and c) the insistence on $\alpha \lambda \dot{n} \theta \varepsilon \iota \alpha$ in the Olbia tablets. ${ }^{7}$ 'A $\lambda \dot{n} \theta \varepsilon \iota \alpha$ is a catchword for the Orphics of Olbia. It is engraved on the tablets in contrast to $\Psi \varepsilon \tilde{\delta} \delta \circ \zeta$, but the insistence lies in the 'A $A \dot{\eta} \theta \varepsilon \iota \alpha$, because of its presence three times in these. This emphasis on "the truth" represents the novel doctrine, the truth revealed to the initiates, contrasted with the error in which the rest people live. 8

In the Pherai-epigram the opposition between doxa-aletbeia is applicable to the fatherhood of Lykophron. If two fatherhoods, one divine, the other human, have to be matched together, it is often said that the human origin was only believed. ${ }^{9}$ In the Greek literature, this opposition is manifest

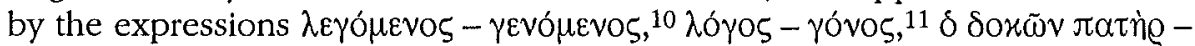

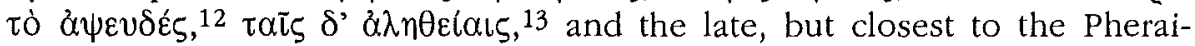

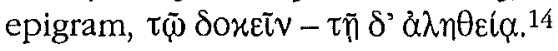

The dual conception of a celestial royal Father and of an earthly great Mother is the religious and pre-philosophical expression, in physical terms, of the primal distinction between incorporeal light and substantial darkness, the opposition between definiteness and indeterminacy. ${ }^{15}$ Besides, the Greek

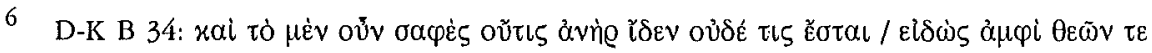

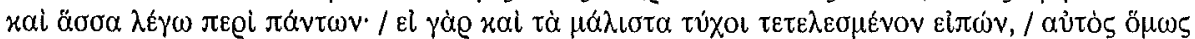

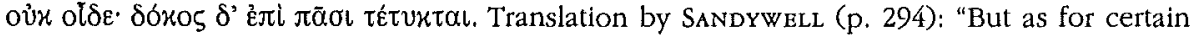
truth, no man has seen it; nor will there ever be a man who knows about the gods and about the things of which I speak. And even if by chance he were to speak the final truth, he himself would nevertheless be aware of it; opinion (seeming) is fixed by fate upon all things" (KIRK-RAVEN-SCHOFIELD, p. 186).

7 Olbia tablets, text: L. DuBors, Inscriptions grecques dialectales d'Olbia du Pont, Genève, 1996, no. 94 with bibliography.

8 See M.L. WEST, "The Orphics of Olbia", ZPE 45 (1982), p. 20.

9 Cf. Gospel of Luke, 3, 23. I would like to express my appreciation to Prof. Dr. D. Zeller, for his kindness to provide me the literary references concerning doxa-aletheia.

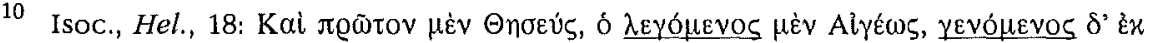

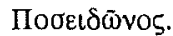

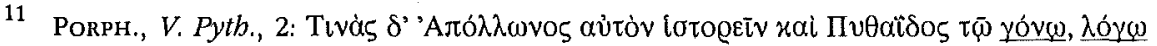

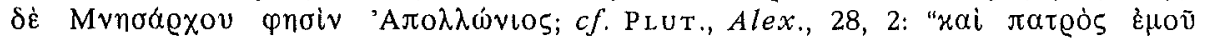

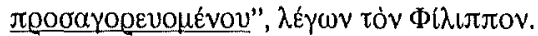

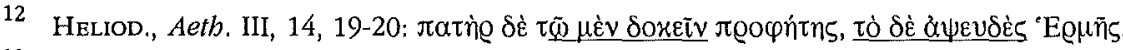

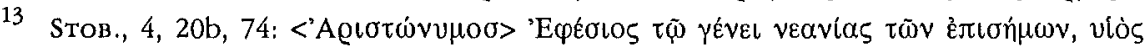

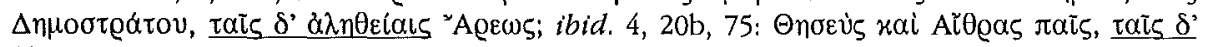

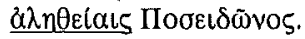

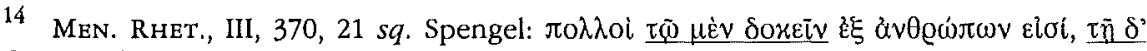

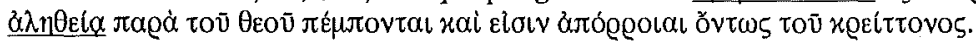

15 See G.E.R. Lloyd, Polarity and Analogy, Cambridge, 1966, esp. ch. II: "The analysis of different modes of opposition", p. 86 sq. and "Imagery in Cosmological Theories", p. 232-247. In general, P.F.M. FonTaine, The Light and the Dark. A Cultural History of Dualism. Vol 1. Dualism in the Archaic and Early Classical Periods of Greek History, Amsterdam, 1986; id., The Light and the Dark. A Cultural History of Dualism. Vol IV. Dualism in the Ancient Middle East, Amsterdam, 1989, p. 46-50, concerning the life after 
view of death is essentially dualistic, as revealed in Greek epitaphs: the body $(\sigma \tilde{\omega} \mu \alpha)$ is separated from the soul ( $\psi v \times \hat{\eta})$ by death. ${ }^{16}$

In this epigram, the deceased Lykophron emphasizes his paternal origin, in particular the divine one, corresponding to the immortal fire. The dead man confesses that his real origin is from $\pi \tilde{\nu} \varrho \alpha$ åd $\theta \alpha$ tov (immortal fire), which

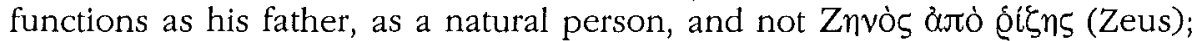
this sounds rationalistic. ${ }^{17}$ Zeus is the effective principle. The fire comes from him, and this element represents spiritual-material substance, generally and specifically. Merkelbach saw a change in traditional beliefs in both of the two couplets. He thinks that this Lykophron was likely from the family of the tyrants of Pherai, Jason and Lykophron, and therefore Sıoyevins. In Greek mythology, many heroes are named after their human fathers, but are actually sons of Zeus. In this funerary epigram, Lykophron, the son of

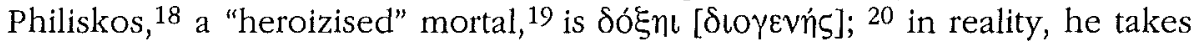
his origin from the $\dot{\alpha} \theta \alpha \dot{v} \alpha \tau o v \pi \tilde{\varrho}$, that is the Aether. Merkelbach is basically right as to the $\delta o ́ \xi \alpha$ : there was some family genealogy, where Zeus was regarded as ancestor, which is replaced by the "true", the physical-mystical interpretation.

Pherecydes of Syros, the reputed teacher of Pythagoras and the first

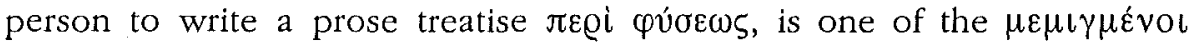
$\theta \varepsilon o \lambda o ́ \gamma o u, 21$ who employed "physiological" conceptual apparatus and argumentation: Chronos, Zas and Chthonie = Earth. In Pherecydes, Zas for Zeus is the aethereal warmth, the principle of light and life.

death in Egypt. Cf. A.L. PIERris, "Origin and Nature of Early Pythagorean Cosmogony", in K.I. Boudouris (ed.), Pythagorean Pbilosopby, Athens, International Center for Greek Philosophy and Culture, 1992, p. 133 sq.

16 R. LAtTIMORE, Themes in Greek and Latin Epitaphs, Urbana Ill., 1942, p. 21. See F.D. Miller Jr., "Philosophical Themes in Early Greek Grave Inscriptions", in XI Congresso Internazionale di Epigrafia Greca e Latina, Roma, 18-24 Settembre 1997, Atti I, Roma, 1999, p. 191-198, who considers the epitaph epigram for the Athenian dead at Poteidaia in 432 as the earliest statement of metaphysical dualism. On this epitaph epigram see infra.

17 See PEEK, o.c. (n. 1),

18 The name Philiskos is evidenced at Demetrias, see B. Helly, Gonnoi II, Amsterdam, 1973, no. 11; also, at Gyrton (inscription from Thaumakoi), BullEpigr (1973), 235 and at Echinos, BullEpigr (1973), 238.

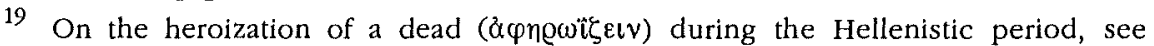
L. FARNELL, Greek Hero Cults and Ideas of Immortality, Oxford, 1921, p. 343-344; W. Burkert, Greek Religion, Oxford, 1985, p. 206; F. Graf, Nordionische Kulte, Rome, 1985, p. 127 sq.; W. SPEYER, "Heros", RAC 14 (1988), p. 868-869.

20 The divine fatherhood is not a necessary condition for a mortal's heroizising: BURKerT, o.c., n. 43, of p. 207 and Graf, o.c., n. 43, of p. 128 and n. 55.

21 Arist., Metaph, 1091 b 8 (A 7). 


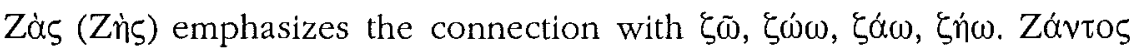
evokes $\zeta \tilde{\omega} v \tau 0 \zeta .22$ Noteworthy in the epigram for Lykophron is the verb $\xi \tilde{\omega}$, clearly referring to Zeus etymologically but also denoting the rebirth of the dead in its semantic context. The author clearly found it congenial to use etymology as a hermeneutic tool to reveal the nature of the divine (Zeus), instead of employing the noun $\psi v \times \dot{n}$. The use of the genitive Znvòs by the writer of the epigram, instead of $\Delta l o \zeta$, reinforces our argument. This is paralleled to the genitive Znvòs used by Heraclitus, fr, $32 \mathrm{D}-\mathrm{K}$. The connection, substantial and etymological, of Zeus with life was widespread in philosophical authors. ${ }^{23}$ Zós, as life spirit and celestial king, is the aethereal principle. ${ }^{24}$

According to Hippocrates, what is called bot, $\theta \varepsilon \varrho \mu o ́ v$, is immortal,

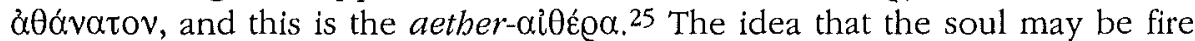
or aether must have helped to determine the choice of fire as the controlling form of matter. Fire is an archetypal form of matter and in the early fifth century Heraclitus provided an exemplary description of the deity: it is the $\pi \tilde{u} \varrho$ d̊i $\zeta \omega o v$, "fire that lives for all eternity." 26 The pure cosmic fire was identified by Heraclitus with aiting (aether), the brilliant fiery stuff which fills the shining sky and surrounds the world; this aether was widely regarded both as divine and as a place of souls.

In Meijer's view, the ordering archè (principle) fire constitutes for Heraclitus what is called the ontic prius, i.e. that principle or principles which precede all else either cosmogonically or cosmologically. Heraclitus calls Zeus "the one Wise" (in fr. $32 \mathrm{D}-\mathrm{K}$ ) and seems to mean that fire can be called Zeus in a certain sense, thereby momentarily giving the concept of god

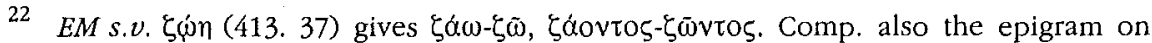

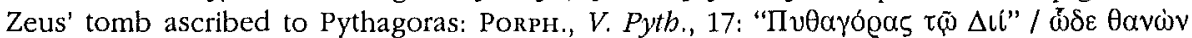

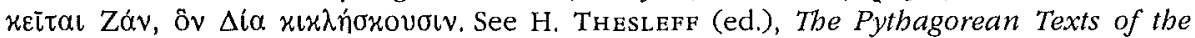
Hellenistic period, Äbo, 1965, p. 174.

23 E.g. Plato, Crat., 396a-b; the Stoics, Diog. Laert, VII, 147; Ar. Did., fr. 29 Diels; Dox. Gr., 464. 28; Connutus, Theol. Graec., 2, p. 3. 3 Lang.

24 Hermeias, Irrisio Gent. Phil., 6, p. 18 Otto; Probus ad Vergil., Bucol. VI, 31.

25 Hippocr, de carnib., 2 (Opera Omnia Littré, VIII, 584) = apud Diog. of APollonia,

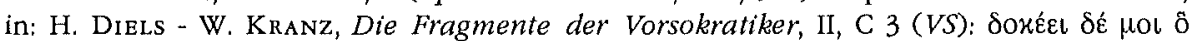

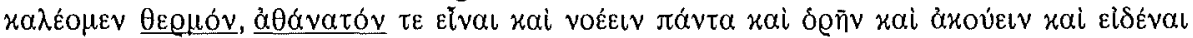

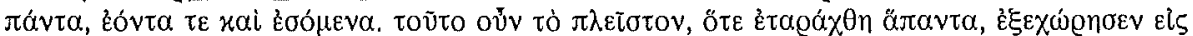

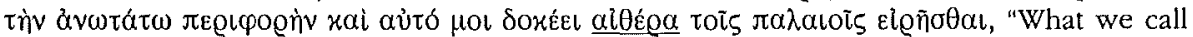
'hot' seems to me to be immortal and to apprehend all things and to see and hear and know all things, both present and future. This, then, the most of all, when all things became confused, went out to the furthermost sphere, and seems to me to have been what was called aether by the men of old". $C f$. also Eur., fr. 839,9 sq.; fr. $941\left(\right.$ Nauck $\left.^{2}\right) ; i d$., Hel., 1014 sq.; Ar., Pax, 832 sq.

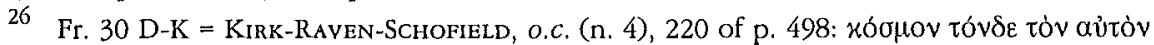

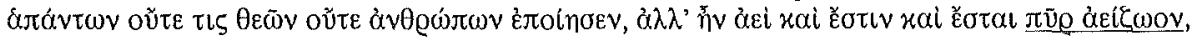

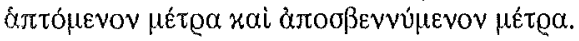


physical form and placing it on the same level as the ontic prius. ${ }^{27}$ Physiology and mystical vision appear to be integrated in Heraclitus. It has been argued by Seaford that the content of Heraclitus' philosophy was related to and derived from the Orphic mysteries, on the basis mainly of its link with the Olbia bone plate, as far as the soul-death-immortality conception is concerned. 28

Diogenes of Apollonia held that the soul was warm air, which seems

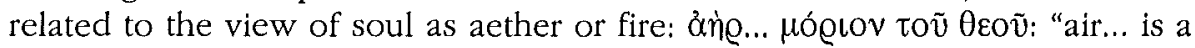
small portion of the god". ${ }^{29}$ Diogenes of Apollonia turned the voũ into áne, thus elevating it into a deity (fr. $5 \mathrm{D}-\mathrm{K}$ ). In this way, the concept of god is simply adapted to the materialistic theory by giving it physical form. The ontic pritus and the deity come here very close to one another, closer than we shall find again in Greek philosophy for many years to come. Even Heraclitus had dared to tread the same path, that of giving the deity physical form. In the vónoıs (intellect) we find a personalized element which makes it perfectly suitable to call the àne $\theta \varepsilon$ ós. Aether is identified with fire in Anaxagoras, too. 30

Scholars have noted that a funerary epigram for the Athenian dead at Poteidaia ( $432 / 1$ B. C.), found near the entrance to the Academy, now in the

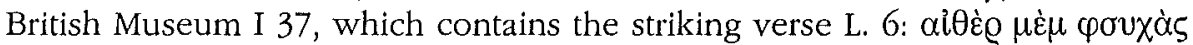

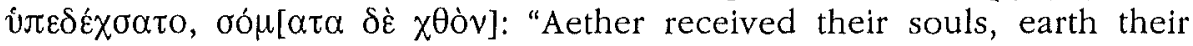
bodies", is the first monument to use this eschatological motive, highly significant in subsequent decades. ${ }^{31}$

When in funerary epigrams appears the statement "the soul of the deceased dwells in the sky", it does not only mean spiritual ascension, but also the continuation of "real" life by the soul after the death of the body. The opposition between the place of the body's rest (earth, tomb) and that of the soul (sky, stars, Isles of Blessed, the Elysian Fields) is a recurring motif in funerary epigrams. 32

27 P.A. MEIJER, "Philosophers, Intellectuals and Religion in Hellas", in H.S. VERSNEL (ed.), Faith, Hope and Worship, Leiden, Brill, 1981, p. 225.

28 See R. SEAFORD, "Immortality, Salvation, and the Elements", HSPh 90 (1986), p. 14$15 \mathrm{sq}$. and notes 58,59 for bibliography.

29 Diog. of Apollonia, in Theophr, de sensu, 39 sq. (D-K 64 A 19) and in KirkRAVEN-SCHOFIELD, o.c. (n. 4), p. 444 sq.

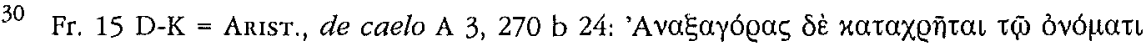

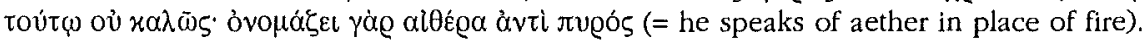

$31 I G \mathrm{I}^{3}, 1179$; also, $I G \mathrm{I}^{2}, 945 ; \mathrm{W} . \mathrm{PEEK}$, Griechische Vers-Inschriften, I. GrabEpigramme, Berlin, 1955 ( $=G V, \mathrm{I}) 20 ; G G, 12$; D.W. BradeEN, The Athenian Agora XVII, no. 16; Ch. Clairmont, ZPE 36 (1979), p. 126-129; id., Patrios Nomos, I, 1983, no. 41 and p. 177. See also Miller, l.c. (n. 16), p. 191-198.

32 See the funerary epigram from Corcyra, (3rd or 2 nd c. B. C.), PeEK, GV, 1978:

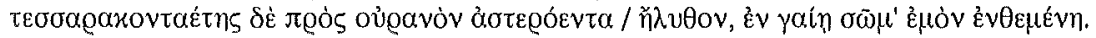


In the Pythagorean Hypomnemata, as they are transmitted by Alexander Anonymous ("Polyhistor"), a Pythagorean philosopher of the late Hellenistic period, everything existing in the aether is immortal and divine; therefore, since the soul is part of the aether, it is immortal. 33

The Derveni Papyrus, ${ }^{34}$ although is less close to the Pherai-epigram, deserves attention because it constitutes an important text for the history of Presocratic culture, where the theme of mixture of the primordial cosmogonic elements and their reciprocal relation in the mystery texts of Orphism, like lamella $\mathrm{C}$ of Thurii, has already been emphasized by scholars. 35 M.L. West has persuasively argued that the commentator of Papyrus Derveni had a vision of the world influenced by Ionic philosophy, as was Diogenes of Apollonia. 36 Thus, in Papyrus Derveni Zeus is presented as follows: 37

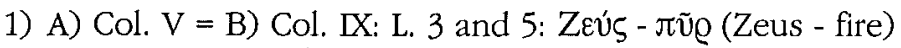

2) A) Col. IX = B) Col. XIII: L. 1 and 4: Zev́s - aîṇ@ (Zeus - Aether)

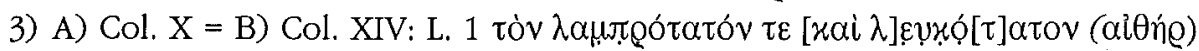
(the brightest and whitest aether)

4) A) Col. XIII = B) Col. XVII: L. 3- 4, 12: ơń = Zzús. (air - Zeus)

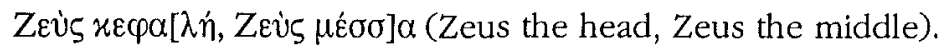

5) A) Col. XV = B) Col. XIX: ảń = Zeús. (air- Zeus)

The commentary on Orphism in the Derveni Papyrus interprets Zeus as the all-pervading, all-subduing Air; his intelligence ( $\varphi \varrho o ́ v \eta \sigma \iota \varsigma$ ), conceived as

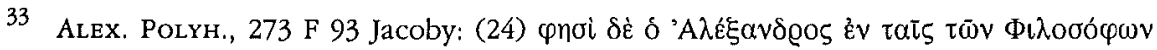

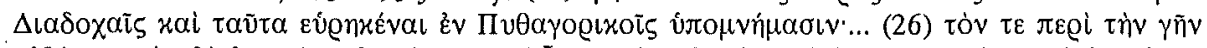

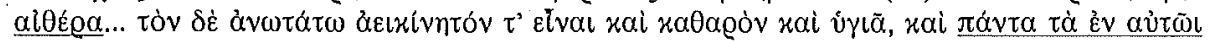

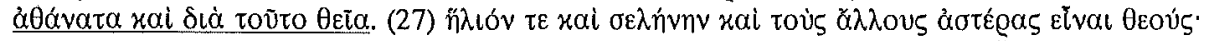

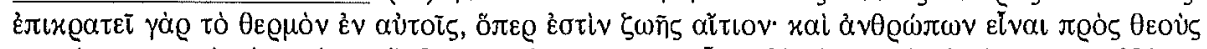

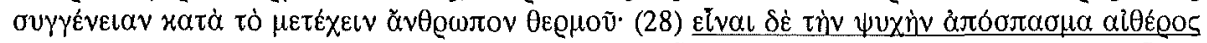

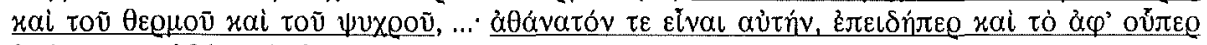

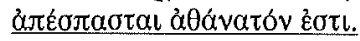

34 On the Derveni Papyrus see the edition by S.G. Kapsomenos, "O 'O@plxós

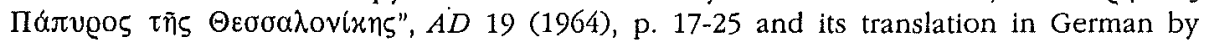
W. BURKERT, "Orpheus und die Vorsokratiker: Bemerkungen zum Derveni-Papyrus und zur pythagoreischen Zahlenlehre", $A \& A 14$ (1968), p. 93-114; also, R. MERKeLBACH, "Der orphische Papyrus von Derveni", ZPE 1 (1967), p. 77-80; an English translation by L.J. Alderink, "Creation and Salvation in Ancient Orphism", American Classical Studies 8 (1981), p. 117-120. Also, the text is published by an anonymous in ZPE 47 (1982), p. 1-12. A. Laks, G.W. Most (eds.), Studies on the Derveni Papymus, Oxford, 1997, esp. M.S. FunGHI, "The Derveni Papyrus", p. 25-37 and D. Оввглк, "Cosmology as Initiation vs. the Critique of Orphic Mysteries", p. 39-54.

35 So e.g. Alderink, l.c. (n. 34), esp. ch. II: "Cosmological origins in the Orphic myths", p. 25-53; cf. SEAFORD, l.c. (n. 28), n. 28.

36 M.L. West, The Opphic Poems, Oxford, 1983, p. 80-81.

37 A) column of text in: $Z P E 47$ (1982), p. 1-12; B) column of text in LAKs-Most, o.c. (n. 34). 
spirit, air in movement, is identified with Orphic Moī $\alpha$. In Diogenes of Apollonia B 4,38 life, breathing and soul go together.

In Orphism, Aether is identified with the impersonal cosmogonic Zeus. This Zeus-Aether is distinct from the personal Olympian Zeus. ${ }^{39}$ On this

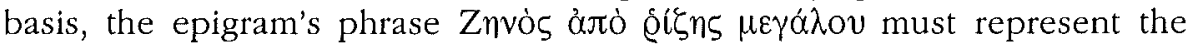

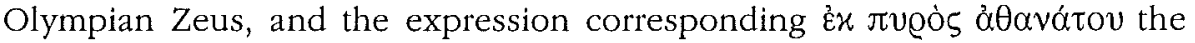
Zeus-Aether, the immortal fire.

I am inclined to believe that the main concept expressed in this funerary epigram for Lykophron is that the deceased 'Orphic' initiate believes in the astral immortality of the soul. ${ }^{40}$ The $\alpha \lambda \dot{\eta} \theta \varepsilon \iota \alpha(=$ truth) in the epigram for Lykophron means that the soul is immortal fire cognate with the stars of heaven. But the fact remains that the natural philosophers had no atheist intentions. We see this confirmed by the Stoa. Aether is the $\pi \tilde{v} \varrho \tau \varepsilon \chi v(x o ́ v .41$ But despite the fact that according to the Stoics fire is the first principle and all else comes from it and is carried along by it, the Stoa is full of religious feeling.

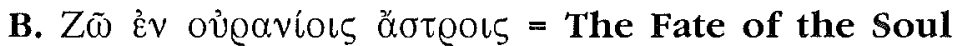

Now, I wish to show how the author of this epigram has combined physiology with a context of eschatology-mystery initiation.

The belief that the soul of the dead is connected with the stars is well established in Greece by the late 5th century; ${ }^{42}$ the "astral eschatology" is first found in Egypt, where the dead are connected with the stars of Orion and Sirius. 43 The notion that the Beyond is in the dominion of the stars and that

38 Simpl, In Pbys, 151, 28 sq.

39 OF 21, 21 a, 168, 297; IoANnis Galenos, diac. Hes., Theog. 943 (Gaisford II 604, 3 sq.); Proclus, at Plato, Tim. E 41 a (III 208, 29-209, 6 Diehl). See S.G. Anemoianni-Sinanidi,

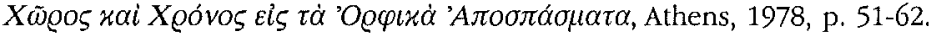

40 See W. Burkert, Lore and Science in Ancient Pythagoreanism, Harvard Univ. Press, Cambridge Massachusetts, 1972, ch. IV: "Astronomy and Pythagoreanism, 4. Harmony of the Spheres and Astral Immortality".

41 The Stoics inherited this theory from Heraclitus and it was typical of their system:

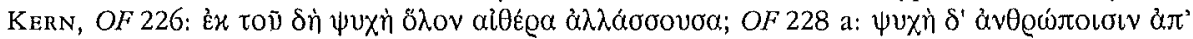

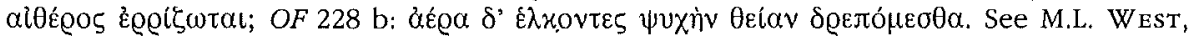
Early Greek Pbilosopby and the Orient, Oxford; 1971, p. 132 sq., p. 150 sq.; id., Orpbic Poems, cit. (n. 36), p. 222-223. Ar. Did., fr. 39. 4 von Arnim (Stoicorum Veterum Fragmenta, Leipzig 1903-1905 (SVF), ii 225. 18)= Poseidonius, fr. 351 Theiler; $c f . S V F$ i. iii. 8, ii 191. 39, 217. 17. Chrysipp., Stoic, 2, 168 sq. Cf. Arist., Mu., 392a 5. Peek, o.c. (n. 1), thinks that this epigram echoes a Stoic doctrine.

42 On the astral immortality after death, see: P. Capelle, De luna stellis lacteo orbe animarum sedibus, Diss. Halle, 1917; E. RHODE, Psyche. The cult of souls and belief of immortality among the Greeks. Transl. from the 8th ed. by W. B. Hillis, London, 1925.

43 R. Bauval, A. Gilbert, The Orion Mystery: Unlocking the Secrets of the Pyramids, London, 1994: "I fly upwards; I am not of the earth, I am of the sky. I am the essence of a god. My soul is a star of gold" quoted by M.R. WRIGHT, Cosmology in Antiquity, 
the soul of man came from the sky and will return there some day was widespread before Pythagoras, and it is explicit in the texts particularly in funerary inscriptions, where Pythagorean influence can be seen. ${ }^{44}$

The close relationship of the human soul with the sky and the stars on the one hand and on the other that, on the basis of this notion, the soul comes from the sky and returns to it, is characteristic of Ionian physiology, at least from Heraclitus' and Anaxagoras' time. 45 For Heraclitus, the soul is composed of fire and survives death. The immortality of the soul is associated in some way with its fiery nature. Moreover, all the various and contradictory ideas about this subject (i.e. of Epicharmus, Alcmeon, Diogenes of Apollonia, Anaxagoras, Parmenides, ${ }^{46}$ Hippasus, Anaximenes) are ascribed by Iamblichus, Aëtius, Maximus Tyrius, and Hippolytus to Pythagoras. ${ }^{47}$

The texts on gold lamellae clearly indicate that, already in the 5 th c. B.C., cosmogonic speculation was related to concern about the soul's fate after death. This explains much about the comprehensive world-view of Heraclitus in particular. ${ }^{48}$ The phraseology of some Orphic gold lamellae suggests that the initiate had it in his power to become a god. In lamella $\mathrm{C}$ from Thurii (Timpone Grande), where Ls, 5 and 8 refer to fire, earth (Demeter), Zeus, the conception of the next world derives partly from mystic ritual, combining an eschatological myth associated with mysteries with three of the divine elements. 49 The Orphic initiate becomes by virtue of his knowledge god through his death, signifying not total annihilation but transformation through rebirth, into another level of being. The genealogy of all versions reflects the status of the soul, an advantage for initiates

London/New York, 1995, esp. p. 109-125. Also, Fontaine, o.c. (n. 15), vol. IV, p. 46-50. For the conflation of Egyptian and Orphic elements see R. MERkelbaCH, "Die goldenen Totenpässe: ägyptisch, orphisch, bakchisch", ZPE 128 (1999), p. 1-13.

44 PEEK, o.C. (n. 31), 648 (also, in $A E, 1953-54$, B, p. 294-296), with a Pythagorean influence, and 1097, 1776, 1829.

45 According to E. PFEIFFER, Studien zum antiken Sternglauben, Leipzig, 1916, p. 114, Heraclitus' theory about cosmos owes much to Pythagoras. See also, K.P. Michaelidis, Menscb und Kosmos in ibrer Zusammengebörigkeit bei den früben griecbischen Denkern, Nicosia, Cypern, 1979, p. 69 sq.

46 See A.C. CAssio, "Da Elea a Hipponion e Leontinoi: Lingua di Parmenide e Testi Epigrafici", ZPE 113 (1996), p. 14-20.

47 The immortality of the soul was one of the basic axioms of the Pythagoreans: Dicaearchus apud Porph., $V, P y t b ., 19$ (= 14 A 8a D-K). Cf. also Iambl., VP, 173, 219; Ä̈t., IV. 7, 1; Maxim. Tyrius X, 2; Hippol., Haer. VI, 25. 4. F. Cumont, Lux Perpetua, Paris, 1949, ch. III: "L'immortalité céleste, Les origines orientales et les Pythagoriciens", p. 143 sq. Also, L. Rougler, La religion astrale des Pythagoriciens, Paris, 1959. For the bibliography on this, J.C. Thom, The Pythagorean Golden Verses, Leiden, Brill, 1995, p. 228 and n. 584.

48 Kirk-Raven-Schofield, o.c. (n. 4), p. 33.

49 See Zuntz, Persephone, Tablet C 5, 8, p. 347-348. R. Seaford, "Dionysiac Drama and the Dionysiac Mysteries", CQ 31 (1981), p. 254. 
demanding special treatment from the gods. 50 The notion that the dead's soul becomes a star influenced Plato's thought. ${ }^{51}$

Initiation connected with knowledge of the fate of the soul occurs particularly in Plato's Phaedo. Plato and the Hippocratic tradition, though critical of initiatory technicians, did embrace the language and imagery of initiation as a vehicle for describing philosophical enlightenment. 52 Plato argued for the immortality of the soul more than any other philosopher. The Phaedo 62b attributes the doctrine that men are in a kind of prison to mystic rites, and in the Cratylus 400c Plato calls Orphic the view that the body is the soul's prison ( $\varphi \varrho \circ$ Q $a$ ). At the end of the Phaedo, the soul divorced from the demands of the body, will go "to a pure home that is above". 53 The destiny of the souls at the end of the Republic also receives a cosmic setting, linked with the Pythagorean theory of the "harmony of the spheres". In the Timaeus, too, the souls were linked to the sky, each one allotted a "consort star". ${ }^{54}$ These myths which specify a celestial origin and destiny for humanity linked themes from Plato's own philosophy with the more widespread belief that souls, made of air, breath or pneuma make their last journey on the death of the body to the upper aether. ${ }^{55}$ In the Menon, $81 \mathrm{~b}$ the rebirth and immortality of the soul echoes an ancient Orphic belief covered by a late platonic dogma about the soul. The eschatological myths in Plato are certainly "Pythagorean". Shamanistic "knowledge" ( $\gamma v \tilde{\omega} \sigma \iota \varsigma)$ about the world and the soul is traced in the most ancient phase of the Pythagorean tradition,

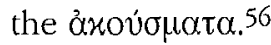

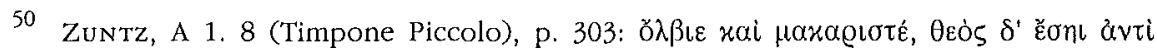

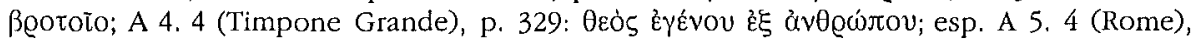
p. 333: $\delta \bar{\imath} \alpha$ $\gamma \varepsilon \gamma \tilde{\omega} \sigma \alpha$.

51 In Plato, Pbdr., as it is shown by J. STENZEL, Kleine Schriften zur griechischen

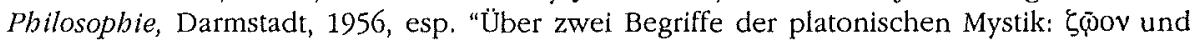
xivnol5" (1914), p. 1 sq., where there is a comparison between Plato, Resp., 621b with Plut., De gen., (Moralia), 591c-f.

52 See OBbink, l.c. (n. 34), p. 53.

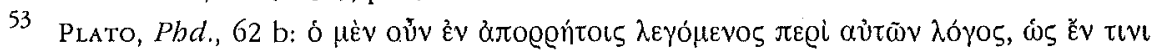

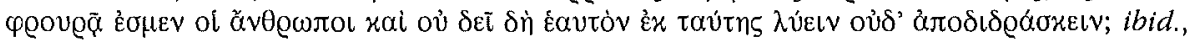
81a; 114b-c. Crat., 400c. See W. WILI, "The Orphic Mysteries and the Greek Spirit, The Mysteries", in Papers from The Eranos Yearbooks, Bollingen Series XXX-2, vol. 2, Pantheon Books, 1955, p. 87-92.

54 Plato, Tim., 41-42b.

55 The popular belief that the place of the pre-existence and post-existence of the soul is a star is expressed in later sources: Plin., II, 8; Eus. Alex., de astr., 1; ARTEM., V, 23. Comp. Cic., Somnium Scipionis, 23, 25; 24, 26; id., Seneca, 6, 7, suggested that "humans have been endowed with souls made out of the everlasting fires called stars and constellations" and the way that leads back to these fires, the circuleus lacteus, Milky Way, where a habitation for all eternity". Cf. Rhode, o.c. (n. 42), p. 363 sq., p. 463 sq

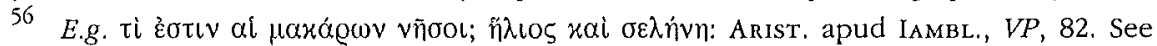
Sandrwell, o.c. (n. 4), p. 214 sq.: The Pythagorean Soul and Metempsychosis. See also I.G. Kalogerakos, Seele und Unsterblichkeit, Untersuchungen zur Vorsokratik bis Embedokles, 
Euripides offers further evidence for a tradition of astral eschatology. In his Suppliant Women, 531-534, read "Let the dead be covered by the earth and whence each part came to light, there let it return - pneuma to aether, the body to earth" and at 1140 the chorus says that "the aether holds now the dead children of Iphis". Also, in the Helen, 1014-1016 say "The mind nous - of the dead has lived its life, but an immortal power is preserved, once it has entered immortal aether". 57 The notion that "when one dies, he becomes a star" is expressed in Aristophanes' Pax, 832-833.58

The same conception pervades the funerary epigram for Lykophron. The deceased initiate proclaims that after his death he dwells in the starry sky, uplifted there by his father. In this way, the mortal Lykophron crosses the boundary of the human sphere and is heroizised.59 This belief about the soul is expressed in a funerary inscription from Phrygia (2nd/3rd c. A.D.): the body of the dead is in his tomb, but his soul lives in the aether of the immortals. ${ }^{60}$ In an epigram about Apollonius of Tyana, a student of Pythagorean doctrines, dated to the 3rd c. A.D., the same notion is expressed: while the body of the deceased (i.e. Apollonius) lay in his tomb at Tyana, in reality, the sky received him. ${ }^{61}$ Also, in Greek funerary epigrams as well as in Latin ones,

Stuttgart/Leipzig, 1996, p. 99 sq.: Pythagoras und die Pythagoreer: Die Seelenwanderungslebre; also, p. 144 sq.: Exkurs i: Die Seelenwanderungslebre in Pythagoreismus und Orphik.

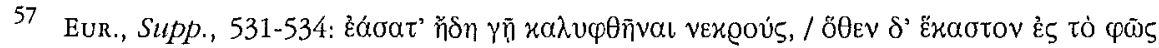

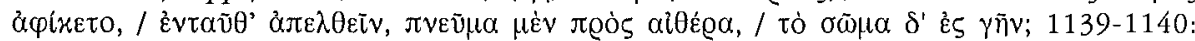

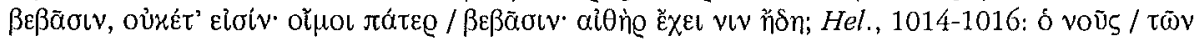

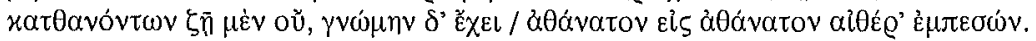

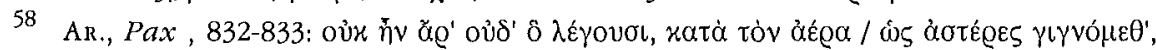

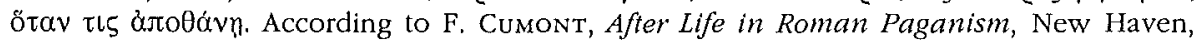
1922, p. 95, Aristophanes' passage is the most exactly dated Greek evidence about the astral immortality. For other examples see Tном, o.c. (n. 47), n. 48, of p. 225 and n. 572.

59 Cp. the epitaph epigram from Marseilles, ca. 250 A.D., now in the Museum at Aix, $C I G$, Sic. It., 2461 (Kaibel, Epigrammata Graeca, 650. Jacobs, AP, Parart., no. 219), where

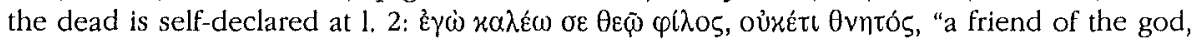

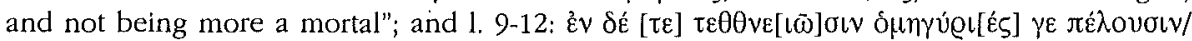

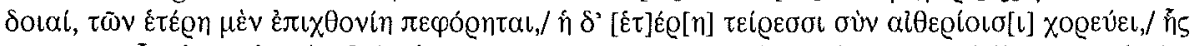

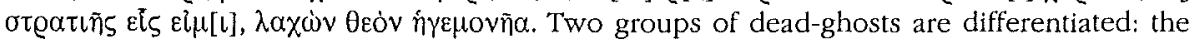
first flies around the earth and the second participates in the chorus of the sky-stars; the dead "is member of the second group, driven there by god". Kaibel rightly discerns an initiation to the Pythagorean and Platonic doctrine (Pbaedrus). Also, the gold lamella

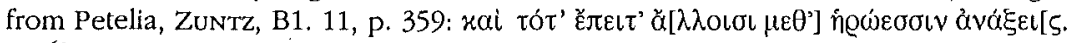

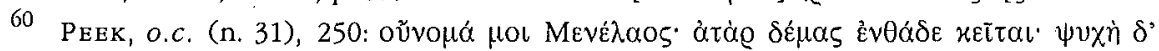

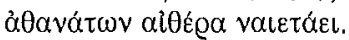

61 I thank Prof. Dr. W. Burkert for this information. See C.P. Jones, "An Epigram on

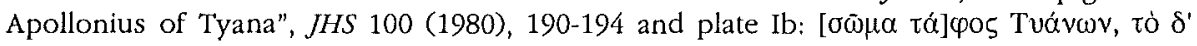

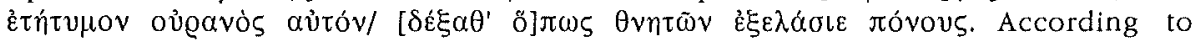
Philostratus, V. Apol. Tyan. VIII 30, Apollonius disappeared from the earth at the temple

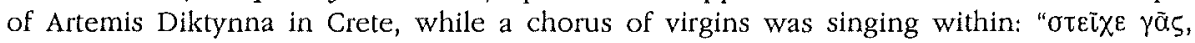

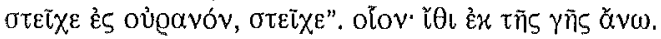


the sky is often the residence of the dead, a point of great significance for understanding the second couplet of our epigram. ${ }^{62}$

In Burkert's view, the notion that "Homeric religion" was followed by a "Pythagorean revolution" is a dangerous over-simplification; but, granted that the mystery cults gave men the hope of escaping death and being joined with the gods, the belief that humans have a divine origin and that with their death they return to the place of their origin easily follows. The initiate aims

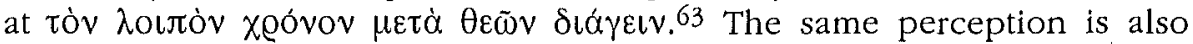

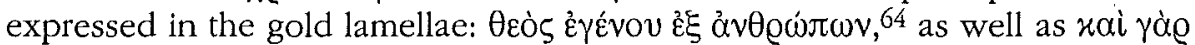

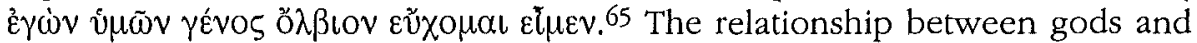

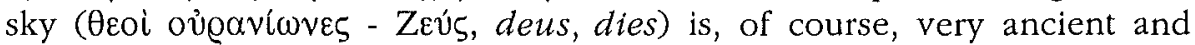
obvious. Dionysus, too, and Bacchus are related to the stars. The catchword in the gold lamellae, group B: "son of earth and starry heaven" refers possibly to Dionysus and the stars. 66

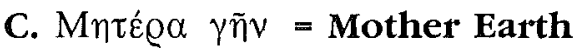

Lykophron, in the last verse of the epigram, states that his body is coming from his mother earth and after his death goes back to her (l. $4: \sigma \tilde{\omega} \mu \alpha \delta \dot{\varepsilon}$

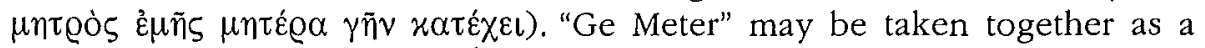
single entity, "Mother Earth". 67 This must not characterise his birth mother, but only express that the son receives his earthly existence from her, he is an earthly son from an earthly mother. 68

The claim that the dead Lykophron's soul makes - "I am the son of Earth and starry Sky" (the last by implication, since $\zeta \tilde{\omega}-\pi \alpha \tau \varrho o ̀ \varsigma$ refer to $\pi \tilde{u} \varrho$ but $\pi \tilde{\nu} \varrho$ $=\alpha \sigma^{\prime}(\varrho \circ \varsigma)$ is puzzling in itself, but presupposes a link between the dead person and the early gods. ${ }^{69}$

62 Lattimore, o.c. (n. 16), p. 27, 28, 34, 313-314. Examples cited in: Peek, GV, I, 861,

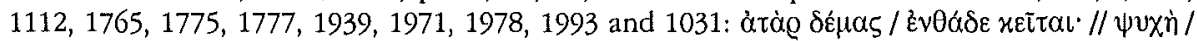

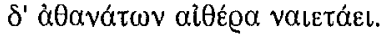

63 Plato, Pbd., $81 a$.

64 Zuntz, A4. 4, p. 329 (Thurii, Timpone Grande).

65 Zuntz, A1. 3, p. 301 (Thurii, Timpone Piccolo).

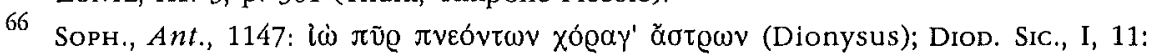

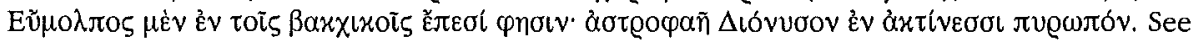
ZUNTZ, p. 364.

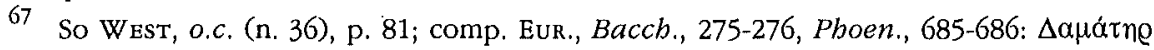

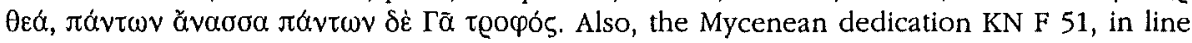
2, perhaps ma-ka, i.e. Mã rã: F. Aura Jorro, F.R. Adrados, Diccionario Micénico, i, Madrid,

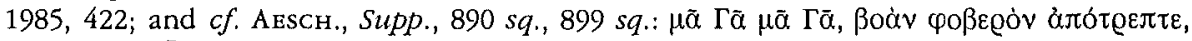
with the $\Sigma$ 's $\omega^{\zeta} \mu \tilde{\eta} \tau \varepsilon \varrho ~ \gamma \tilde{\eta}$; Herod., I, 85; Theoc., 15, 89 (Sicilian?).

68 Comp. KalBel, Epigrammata Graeca, 606 (PeEK, $G V, 441,4$ ), 2nd or 3rd c., from

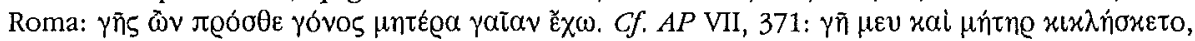

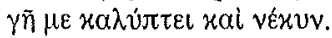

69 KIRK-RAVEN-SCHOFIELD, o.c. (n. 4), p. 30. 
In Papyrus Derveni the same polyonymy is displayed: "Ge (Earth) and Meter (Mother) are one and the same" ${ }^{70}$

On the Petelia Tablet and in the gold lamella from Pharsalos, as well as in that from Eleutherna of Crete, when the Orphic initiate appears before the guardians of Hades, he confesses that his origin refers to Ge and the starry Heaven, but emphasizes that his lineage is celestial. ${ }^{71}$ In the gold plaque from

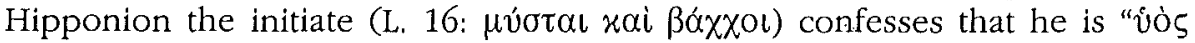

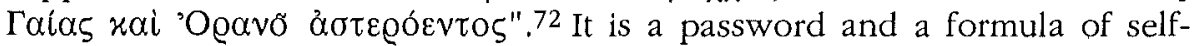
presentation of the mystes for the immortality of his soul. This formula constitutes the anthropology of self-definition of the initiate, who, as a being, is partly earthly, partly divine. ${ }^{73}$ Therefore, the initiate has a "dual potentiality"; the earthly and the heavenly are united in him, and this is his substance. ${ }^{74}$ According to Zuntz, this self-definition of the initiate goes back to Pythagoras. ${ }^{75}$ "Mother Earth" is common, but used in Orphism too. ${ }^{76}$ The entire fourth verse of the epigram for Lykophron clearly echoes the initiate's confession of the Orphic texts " $\Gamma \tilde{\eta} \zeta \pi \alpha \tilde{\iota} \zeta$ cilui"; thus, Merkelbach's suggestion

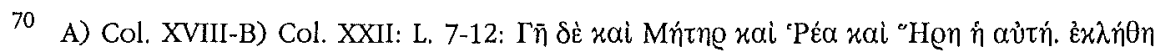

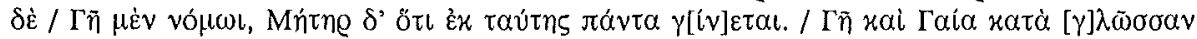

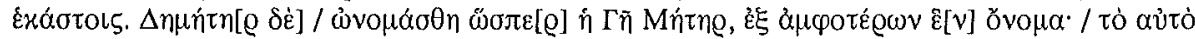

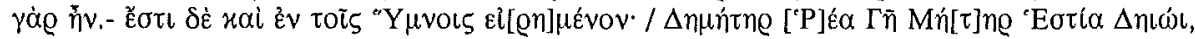
"Earth (Ge), Mother (Meter), Rhea, and Hera are one and the same. She was called Earth (Ge) by custom; Mother, because all things are born from her; Ge and Gaia, according to each one's dialect. She was named Demeter, just like Ge-meter: one name from both, for it was the same. And it is said in the Hymns too: Demeter Rhea Ge Meter Hestia Deio".

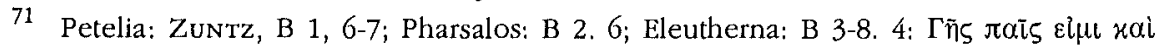

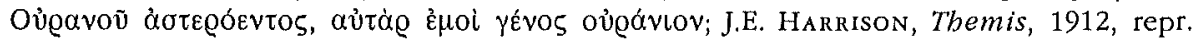
London, 1977, 464; ead., Prolegomena, 1903, repr. London, 1980, p. 659, 661.

72 After G. Pugliese Carratelli, "Un sepolcro di Hipponion e un nuovo testo orfico", PP 29 (1974), p. 108-126, and $i d$., "Ancora sulla lamina orfica di Hipponion", PP 31 (1976), p. 458-466, p. 10-16.

73 Cp. the stele from Eretria, of the 3rd c. B. C. (IG XII 9, 290): $\varepsilon \dot{l} \theta \varepsilon \dot{\zeta} \zeta \dot{\varepsilon} \sigma \theta^{\prime} \dot{\eta} \gamma \tilde{\eta}, x \alpha \dot{\alpha} \hat{\omega}$

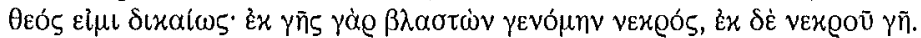

74 See H.D. Betz, "'Der Erde Kind bin ich und des gestirnten Himmels'. Zur Lehre vom Menschen in den orphischen Goldplättchen", in Fr. GraF (ed.), Ansichten Geburstags-Symposium für Walter Burkert, Basel 15-18 März 1996, Stuttgart/Leipzig, Teubner, 1998, p. 399-419.

75 Zuntz, Persephone, p. 383-385.

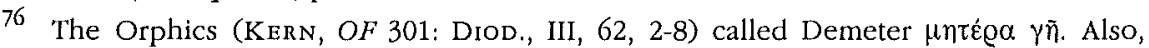
Kern, of 302: Diod., I, 12, 4; Euseb., Praep. evang. III, 3, 5 (I 108, 6 Dind.); Theodoret.,

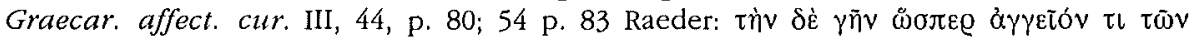

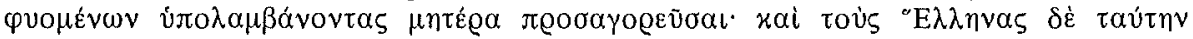

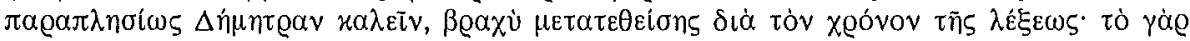

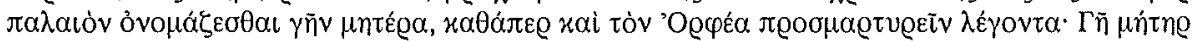

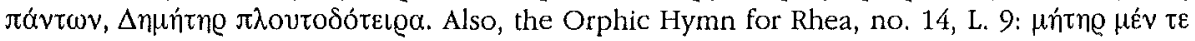

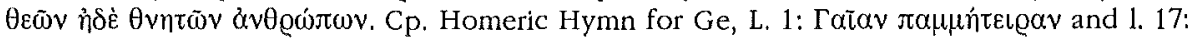

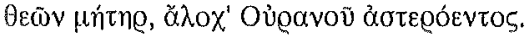


that the ash of Lykophron covers the earth is wrong. ${ }^{77}$ According to Burkert, the initiate's confession of his origin before the guardians of the Underworld is an indication that the mysteries used myths differently, that is, to establish privilege through genealogy. Origin is the decisive declaration made by the initiate in Hades, as witnessed by the texts of the 'Orphic'-Bacchic gold leaves and perhaps this is the reason why it was used as the password. The story of origin is a fact known only to the initiate, not to those outsiders who are ignorant of the secret. 78

\section{Orphism at Pherai}

Archaeological excavations have brought to light important evidence about the existence of local "Orphic-Dionysiac" ("Bacchic") mysteries at Pherai. Brimo, the Orphic Persephone, and Andrikepaidothyrsos, probably the Herikepaios (Erikepaios or Erikapaios) of the Orphic texts, (an Orphic deity identified with Dionysus), are mentioned on the inscribed gold lamella (dated to the 2 nd half of the 4th c. B.C.), found in the south cemetery of Pherai in 1970 and probably coming from the tomb of an Orphic initiate.79 The 'Orphic' text from Pherai is new and decisive as to the relevance of 'Orphism' in that place. A couplet engraved on a gold lamella from a tomb of the same date is further evidence for "Orphic" activity at Pherai, because it names Demeter Chthonia, the mother of the Orphic Persephone. ${ }^{80} \mathrm{P}$. Chrysostomou argues that the absence of such Orphic deities of the Underworld in similar inscriptions (lamellae) elsewhere in Thessaly suggests that their cult was limited to a small number of private gatherings at Pherai and that it was not an official cult. These local mystery cults are characterizised as "Orphic- Bacchic", as is the case of those mentioned in the gold lamellae at Pelinna (end of the 4th c. B.C.), where Persephone and Bacchios, the Orphic Dionysus, are the gods of the mysteries. ${ }^{81}$

\section{E. Conclusions}

The funerary epigram for Lykophron brings another dimension of "Orphism" at Pherai to light: the initiate's belief in his origin from the immortal fire (sky) and in the astral immortality of his soul. Both of these

77 See Merkelbach, o.c. (n. 1)

78 W. Burkert, Ancient Mystery Cults, Cambridge/London, 1987, p. 76.

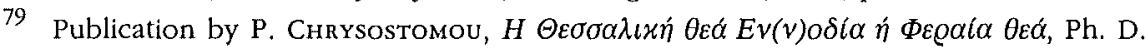
Univ. of Thessaloniki, 1991, p. 371 sq., published: Athens, 1998, p. 210 sq.; BullEpigr (1997),

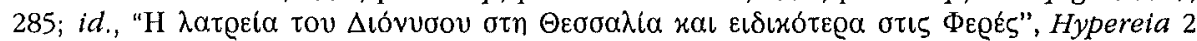

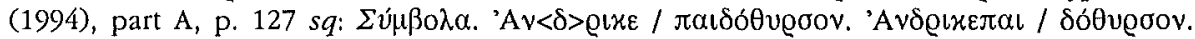

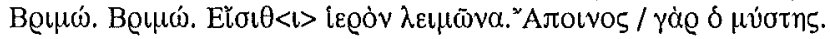

80 A. Arvanitopoulos, PAAH (1907), p. 160.

81 See K. Tsantsanoglou, G.M. Parassoglou, "Two Gold Lamellae from Thessaly", Hellenica 38 (1987), p. 10. 
elements are rooted in the Pythagorean tradition. At any rate, the content of the epigram belongs to the "Orphic" climate existed at Pherai. Lykophron, the heroizised mortal, has ensured his immortality after his death, perhaps by being an initiate of the "Orphic"-Bacchic"-"Pythagorean" doctrines. His immortality is elemental (fire) and personal (fiery soul). His "heroization" is gained thanks for the post-mortem blessedness of the survival of his soul in the starry heaven. Lykophron in this quality becomes one of those figures who remain close to everyday life but at the same time transgress the bounds of the chthonic realm to enter the divine sphere.

In my view, the main conceptual dualism and opposition lies in $\Sigma \Omega M A$ $\Psi$ YXH (Body-Soul), - compare the graffiti $\Sigma \Omega M A-\Psi Y X H$ on the Olbia bones -, corresponding to the physiological elements Earth (Ge-Mother) and immortal fire (Zeus-Father), lower and upper worlds (underground and starry heaven). The contrast between $\triangle O \Xi A-A \wedge H \Theta E I A$ (Seeming-Truth) in the epigram reveals the Presocratic reflexibility existing in the construction of philosophical discource c. 600-450 B.C., especially in Parmenides and Xenophanes; ${ }^{82}$ the $A \Lambda H \Theta E I A$ (Truth) in the epigram means for Lykophron that the soul is immortal fire cognate with the stars of heaven, and $A \Lambda H \Theta E I A$ is a catchword for Orphism, as the graffiti A $\Lambda H \Theta E I A-\Psi E Y \Delta O \Sigma$ on the Olbia tablets indicate, with A $\Lambda H \Theta E I A$ inscribed three times.

It is clear that the four verses of the Pherai-epigram presuppose and trace back to previous texts and beliefs; furthermore, we could argue that the axiom: "physiology should not be regarded as an odd, alien kind of instruction for mystic initiates" 83 is applicable to this epigram. It seems, finally, that these diffused ideas were "common possession" and perhaps the cogency of the argumentation about "local particularities", because of differences in the details, has no effect. ${ }^{84}$ As far as the identity of the poet of this funerary epigram is concerned, I can affirm only that he appears to have been an intellectual, well versed in Presocratic cosmogony interwoven with mystic doctrines of his time. Exactly who he was remains an open question.

Aphrodite A. Avagianou

Athens, Spring 2001

82 See SANDYWELL, o.c. (n. 4), p. 300 sq.

83 Seaford, l.c. (n. 28), p. 20; ObBink, l.c. (n. 44). Also, esp. Chr. Schefer, "Nur für Eingeweihte!' Heraklit und die Mysterien", Antike und Abendland 46 (2000), p. 46-75.

84 My sincere thanks go to Prof. Y. Tzifopoulos, to whom I owe this remark per litteras. 